\title{
Correction to: The Potential of Reformed Slag on the Mechanical and Thermal Behaviour of Toughened Unsaturated Polyester Composites
}

\author{
Ahmad Mousa $^{1}$ (D) Udo Wagenknecht ${ }^{2} \cdot$ Michaela Gedan Smolka $^{2}$
}

Published online: 24 July 2019

C) Springer Nature B.V. 2019

\section{Correction to: Waste and Biomass Valorization https://doi.org/10.1007/s12649-019-00741-7}

The third author name was incorrectly published in the original publication of the article. The third author name should be Michaela Gedan Smolka.

The original article has been corrected.

Publisher's Note Springer Nature remains neutral with regard to jurisdictional claims in published maps and institutional affiliations.

The original article can be found online at https://doi.org/10.1007/ s12649-019-00741-7.

Ahmad Mousa

mousa@ rocketmail.com

1 Department of Materials Engineering, Faculty of Engineering, Al- Balqa Applied University, Salt 19117, Jordan

2 Leibniz-Institut für Polymerforschung Dresden e. V, Hohe Strasse 6, 01069 Dresden, Germany 